\title{
Opportunities for Getting Rust Modifications on the Base of Local Resources for Corrosive Surface
}

\author{
Jumaniyazov Maqsud Jabbiyevich, Ermetov Amirbek Ismailovich, \\ Kuranbayev Sherzod Raimberganovich \\ Department of Chemical Technology, Chemical-Technological Faculty, Urgench State University, Urgench City, Uzbekistan
}

Email address:

goodluck_0714@mail.ru (E.A. Ismailovich)

\section{To cite this article:}

Jumaniyazov Maqsud Jabbiyevich, Ermetov Amirbek Ismailovich, Kuranbayev Sherzod Raimberganovich. Opportunities for Getting Rust Modifications on the Base of Local Resources for Corrosive Surface. American Journal of Materials Synthesis and Processing. Vol. 3, No. 2, 2018, pp. 30-33. doi: 10.11648/j.ajmsp.20180302.14

Received: June 19, 2018; Accepted: July 6, 2018; Published: August 8, 2018

\begin{abstract}
In this article, $22 \%$ of the phosphoric acid content is derived from surfactants, corrosion inhibitors and industrial waste densities that have an artificial resource and study advanced rust modifiers. Adding exterior-active substances, corrosion inhibitors and technogen resources to $22 \%$ phosphate acid. In order to create optimal composition of multi-functional rust modifications and analyzing available products with chemical and physical methods. Modern physical-chemical methods, $\mathrm{X}$ ray phased, IR- spectroscopic research are used. Melting diagram of $22 \% \mathrm{H}_{3} \mathrm{PO}_{4}-\left(\mathrm{CH}_{2}\right)_{6} \mathrm{~N}_{4}-\mathrm{C}_{5} \mathrm{H}_{6} \mathrm{O}_{2}$ triple polythermal system has been investigated for the first time and modifier with new composition has been synthesized. As a result of total scientific research, the new technology of getting chemical refining modifiers from competitive multi-functional rust has been founded. Taking everything into account, results, taken on the base of studying melting level in $\left[22 \% \mathrm{H}_{3} \mathrm{PO}_{4}+78 \% \mathrm{H}_{2} \mathrm{O}\right]-\left(\mathrm{CH}_{2}\right)_{6} \mathrm{~N}_{4}-$ $\mathrm{C}_{5} \mathrm{H}_{6} \mathrm{O}_{2}$ system, lead to the creation of new technology of getting new rust modifiers on the base of extractive phosphate acid, furfural alcohol and hexamethylenetetramine.
\end{abstract}

Keywords: Phosphate Acid, Hexamethylenetetramine, Lignin, Modifier, Inhibitor, Solubility of Polytreme IR-Spectroscopy, Differential Thermo Analysis, Furfural

\section{Introduction}

According to the analysis of scientific research all over the world till now, there is very few amount of scientific information on the solution of issues, including, refining corrosive remains, old paints and oil substances on the surface of metals. Available ones are for the purpose of mechanic refining of surfaces, and based on hard work and large quantity of energy. This type of refining cannot be used in high buildings and main pipes situated on desert zones. In addition to this, it may cause to the collapse of metal base [1-4].

According to the above mentioned reasons, today's one of the most significant issues is creating modern and competitive types of effective refining products on the base of local resources for corrosive surfaces. In its turn, this leads to the decrease in the import of this product to the country and this scientific work is included as a scientific research to the development of national economy. Rust modifications, energy saver, substituted for import and aimed at export, and recycled from industry waste products and local resources, will be applied for being produced on the base of high technology [4-5].

It is well known that, corrosive products, instead of iron oxide, form as phosphorous compounds or as a phosphate crusts on the surfaces when the passivation of oxidized parts of metal products with the solution of phosphate acid. These crusts are connected chemically with metal bases; consist of the small microscopic-sized crystals that grow jointly. In order to form phosphate crusts in the solution, there should be optimal concentration of phosphate acid. High level of phosphate acid may lead to melting process of metal and burn of rust and iron. As a result of easy oxidation of Iron (II) phosphate, phosphate crusts are not be able to do the function of protection, it means that when the phosphate concentration is low, it cannot modify the rusts on the surface of the metal completely. 


\section{Methods}

In order to avoid available corrosive products, it is recommended to add out-active substances, acid-corrosive inhibitors and other compounds to the corrosion competitive layer on the base of extractive phosphate acid. Hexamethylenetetramine, furfural alcohol, hydrolysis lignin are the substances that include these characteristics in themselves. However, when clarifying the technology of effective rust modifications, include above-mentioned substances, physically and chemically, it is required to have the values of extractive phosphate acid with their components melting politrems [6-7].

Aim: Adding exterior-active substances, corrosion inhibitors and technogen resources to $22 \%$ phosphate acid In order to create optimal composition of multi-functional rust modifications and analyzing available products with chemical and physical methods.

Methods of research: Modern physical-chemical methods, X-ray phased, IR- spectroscopic research are used.

Scientific novelties: Melting diagram of $22 \% \mathrm{H}_{3} \mathrm{PO}_{4}$ $\left(\mathrm{CH}_{2}\right)_{6} \mathrm{~N}_{4}-\mathrm{C}_{5} \mathrm{H}_{6} \mathrm{O}_{2}$ triple polythermal system has been investigated for the first time and modifier with new composition has been synthesized. As a result of total scientific research, the new technology of getting chemical refining modifiers from competitive multi-functional rust has been founded.

Gathered Information: When solubility of polytreme has been studied, this type of new compositions occurs: $\left(\mathrm{CH}_{2}\right)_{6} \mathrm{~N}_{4} * \mathrm{H}_{3} \mathrm{PO}_{4} * 4 \mathrm{H}_{2} \mathrm{O}, \quad\left(\mathrm{CH}_{2}\right)_{6} \mathrm{~N}_{4} * \mathrm{H}_{3} \mathrm{PO}_{4} * 2 \mathrm{H}_{2} \mathrm{O}$, $\left(\mathrm{CH}_{2}\right)_{6} \mathrm{~N}_{4} * \mathrm{H}_{3} \mathrm{PO}_{4} * \mathrm{H}_{2} \mathrm{O}, \mathrm{H}_{3} \mathrm{PO}_{4} *\left(\mathrm{CH}_{2}\right)_{6} \mathrm{~N}_{4}$

It has been proved that these compositions are individual substances by above-mentioned methods. It leads to the synthesis of modifier with new composition.

\section{Materials and Results}

We began the work with studying the interaction of Hexamethylenetetramine, furfural alcohol and extractive phosphate acid in order to add exterior-active substances, corrosion inhibitors and technogen resources to $22 \%$ phosphate acid. For that reason, we studied the melting diagram of $22 \% \quad \mathrm{H}_{3} \mathrm{PO}_{4}-\quad\left(\mathrm{CH}_{2}\right)_{6} \mathrm{~N}_{4}-\mathrm{C}_{5} \mathrm{H}_{6} \mathrm{O}_{2} \quad$ triple polythermal system [7-8].

While studying the diagram, it is found out that melting level of hexamethylenetetramine with furfural alcohol decreases to $14 \%$ from $46,6 \%$ on $22 \%$ phosphate acid. While studying this triple system, new four substances have been found and all the information about the composition of chemical compounds is given in Table 1 .

Table 1. Chemical composition of new-found compositions taken from hexamethylenetetramine and furfural alcohol.

\begin{tabular}{|c|c|c|c|c|c|c|}
\hline \multirow{2}{*}{ Compound } & \multicolumn{3}{|c|}{ Found mass. \% } & \multicolumn{3}{|c|}{ Accounted. mass. \% } \\
\hline & $\mathrm{H}_{3} \mathrm{PO}_{4}$ & $\left(\mathrm{CH}_{2}\right)_{6} \mathrm{~N}_{4}$ & $\mathrm{H}_{2} \mathrm{O}$ & $\mathrm{H}_{3} \mathrm{PO}_{4}$ & $\left(\mathrm{CH}_{2}\right)_{6} \mathrm{~N}_{4}$ & $\mathrm{H}_{2} \mathrm{O}$ \\
\hline$\left(\mathrm{CH}_{2}\right)_{6} \mathrm{~N}_{4 *} \mathrm{H}_{3} \mathrm{PO}_{4 *} 4 \mathrm{H}_{2} \mathrm{O}$ & 31.56 & 45.22 & 23.22 & 31.61 & 45.16 & 23.23 \\
\hline$\left(\mathrm{CH}_{2}\right)_{6} \mathrm{~N}_{4} * \mathrm{H}_{3} \mathrm{PO}_{4} * 2 \mathrm{H}_{2} \mathrm{O}$ & 35.80 & 51.05 & 13.15 & 35.77 & 51.09 & 13.14 \\
\hline$\left(\mathrm{CH}_{2}\right)_{6} \mathrm{~N}_{4} * \mathrm{H}_{3} \mathrm{PO}_{4} * \mathrm{H}_{2} \mathrm{O}$ & 23.71 & 67.86 & 8.43 & 23.67 & 67.63 & 8.70 \\
\hline $\mathrm{H}_{3} \mathrm{PO}_{4 *}\left(\mathrm{CH}_{2}\right)_{6} \mathrm{~N}_{4}$ & 41.23 & 58.77 & - & 41.18 & 58.82 & - \\
\hline
\end{tabular}

X-ray phased analyses are done with the facility called DRON-2. Distance among phases is found out with the comparison of intensity of diffraction lines.

Radiography of synthesized compounds show that the absence of reflex related to initial substances, individuality and purity of new compounds [9-12].

New synthesized $\left(\mathrm{CH}_{2}\right)_{6} \mathrm{~N}_{4} * \mathrm{H}_{3} \mathrm{PO}_{4} * \mathrm{H}_{2} \mathrm{O}$; $\left(\mathrm{CH}_{2}\right)_{6} \mathrm{~N}_{4} * \mathrm{H}_{3} \mathrm{PO}_{4} * 2 \mathrm{H}_{2} \mathrm{O}$; $\left(\mathrm{CH}_{2}\right)_{6} \mathrm{~N}_{4} * \mathrm{H}_{3} \mathrm{PO}_{4} * 4 \mathrm{H}_{2} \mathrm{O}$; $\mathrm{H}_{3} \mathrm{PO}_{4 *}\left(\mathrm{CH}_{2}\right)_{6} \mathrm{~N}_{4}$ compounds have individual crystal net. Radio graphical analysis results are given in the Table 2.

Table 2. Distance through planes and relative intensity of hexamethylenetetramine and its components on radio graph.

\begin{tabular}{|c|c|c|c|c|c|c|}
\hline Compounds & d. $\AA \AA$ & I. $\%$ & d. $\AA$ & I. $\%$ & d. $\AA$ & I. $\%$ \\
\hline 1 & 2 & 3 & 4 & 5 & 6 & 7 \\
\hline \multirow{6}{*}{$\left(\mathrm{CH}_{2}\right)_{6} \mathrm{~N}_{4}$} & 12.107 & 9.0 & 4.618 & 25.0 & 2.415 & 15.5 \\
\hline & 8.321 & 17.0 & 4.035 & 70.0 & 2.190 & 100.0 \\
\hline & 7.794 & 21.0 & 3.602 & 15.0 & 2.913 & 99.0 \\
\hline & 7.117 & 24.0 & 3.199 & 91.5 & 1.756 & 32.0 \\
\hline & 6.398 & 49.0 & 2.647 & 85.4 & 1.655 & 13.0 \\
\hline & 5.858 & 69.8 & 2.570 & 11.0 & 1.585 & 40.0 \\
\hline \multirow{7}{*}{$\left(\mathrm{CH}_{2}\right)_{6} \mathrm{~N}_{4} \cdot \mathrm{H}_{3} \mathrm{PO}_{4^{*}} \mathrm{H}_{2} \mathrm{O}$} & 5.752 & 41.5 & 3.106 & 50.0 & 1.885 & 6.5 \\
\hline & 5.262 & 38.5 & 2.712 & 30.0 & 1.857 & 6.0 \\
\hline & 5.074 & 58.0 & 2.443 & 15.0 & 1.775 & 6.8 \\
\hline & 4.706 & 100.0 & 2.402 & 14.0 & 1.734 & 3.5 \\
\hline & 4.307 & 98.0 & 2.212 & 13.0 & 1.707 & 4.5 \\
\hline & 3.507 & 36.0 & 2.211 & 18.0 & 1.6482 & 5.0 \\
\hline & 3.366 & 23.0 & 2.023 & 12.5 & - & - \\
\hline \multirow{4}{*}{$\left(\mathrm{CH}_{2}\right)_{6} \mathrm{~N}_{4} * \mathrm{H}_{3} \mathrm{PO}_{4 *} 2 \mathrm{H}_{2} \mathrm{O}$} & 8.279 & 30.0 & 2.894 & 24.0 & 2.036 & 11.0 \\
\hline & 6.398 & 32.0 & 2.862 & 21.0 & 2.017 & 14.0 \\
\hline & 5.578 & 46.0 & 2.775 & 76.5 & 1.990 & 13.5 \\
\hline & 5.262 & 85.0 & 2.590 & 32.5 & 1.941 & 9.5 \\
\hline
\end{tabular}




\begin{tabular}{|c|c|c|c|c|c|c|}
\hline Compounds & d. $\AA \AA$ & I. \% & d. $\AA$ & I. \% & d. $\AA$ & I. $\%$ \\
\hline 1 & 2 & 3 & 4 & 5 & 6 & 7 \\
\hline \multirow{17}{*}{$\left(\mathrm{CH}_{2}\right)_{6} \mathrm{~N}_{4^{*}} \mathrm{H}_{3} \mathrm{PO}_{4^{*}} 4 \mathrm{H}_{2} \mathrm{O}$} & 5.140 & 53.0 & 2.525 & 13.0 & 1.832 & 9.0 \\
\hline & 4.947 & 98.0 & 2.450 & 15.0 & 1.717 & 15.5 \\
\hline & 4.468 & 100.0 & 2.405 & 27.0 & 1.707 & 6.0 \\
\hline & 3.759 & 31.5 & 2.280 & 16.0 & 1.617 & 5.0 \\
\hline & 3.469 & 20.0 & 2.180 & 18.5 & 1.593 & 5.5 \\
\hline & 3.255 & 92.0 & 2.170 & 33.5 & - & - \\
\hline & 9.453 & 40.0 & 3.308 & 74.0 & 2.044 & 24.0 \\
\hline & 7.779 & 28.0 & 2.534 & 25.0 & 2.016 & 10.0 \\
\hline & 5.344 & 30.0 & 2.462 & 20.0 & 1.917 & 12.0 \\
\hline & 5.235 & 42.0 & 2.332 & 66.5 & 1.618 & 11.5 \\
\hline & 5.162 & 81.0 & 2.320 & 31.5 & 1.391 & 8.5 \\
\hline & 5.270 & 51.0 & 2.221 & 12.0 & 1.732 & 8.0 \\
\hline & 4.631 & 95.0 & 2.110 & 14.0 & 1.511 & 14.5 \\
\hline & 4.421 & 99.0 & 2.305 & 26.0 & 1.302 & 5.0 \\
\hline & 3.568 & 30.2 & 2.310 & 15.0 & 1.419 & 4.0 \\
\hline & 3.571 & 24.0 & 2.380 & 17.5 & 1.693 & 4.5 \\
\hline & 3.324 & 94.0 & 2.370 & 32.5 & - & - \\
\hline
\end{tabular}

Hexamethylenetetramine and its new compounds with extractive phosphate acid are studied with IK- spectroscopic method. Analysis results are given in $3^{\text {rd }}$ Table. IK- specters of compounds on the basis of hexamethylenetetramine and phosphate acid differ completely from the specter of hexamethylenetetramine (Table 3).

Table 3. IK-spectroscopic results of hexamethylenetetramine and its new compounds with extractive phosphate acid.

\begin{tabular}{|c|c|c|c|c|}
\hline \multirow{2}{*}{ Proper functional groups } & \multicolumn{4}{|l|}{ Compounds } \\
\hline & $\left(\mathrm{CH}_{2}\right)_{6} \mathrm{~N}_{4}$ & $\left(\mathrm{CH}_{2}\right)_{6} \mathrm{~N}_{4} \mathrm{H}_{3} \mathrm{PO}_{4} \cdot \mathrm{H}_{2} \mathrm{O}$ & $\left(\mathrm{CH}_{2}\right)_{6} \mathrm{~N}_{4} \mathrm{H}_{3} \mathrm{PO}_{4} \cdot 2 \mathrm{H}_{2} \mathrm{O}$ & $\left(\mathrm{CH}_{2}\right)_{6} \mathrm{~N}_{4} \mathrm{H}_{3} \mathrm{PO}_{4} \cdot 4 \mathrm{H}_{2} \mathrm{O}$ \\
\hline $\mathrm{H}(\mathrm{OH})$ & - & 3380.3320 & 3350.3170 & 3390.3370 \\
\hline $\mathrm{H}\left(\mathrm{CH}_{2}\right)$ & 2880.2956 & 2800.2760 & 2820.2730 & 2930.2730 \\
\hline $\mathrm{H}\left(\mathrm{H}_{2} \mathrm{O}\right)$ & - & 1600 & 1600 & 1600 \\
\hline $\mathrm{H}\left(\mathrm{CH}_{2}\right)$ & 1438.1450 & 1450.1400 & 1470 & 1470 \\
\hline $\mathrm{H}(\mathrm{CN})$ & 1370 & - & - & - \\
\hline $\mathrm{H}(\mathrm{CN})$ & 1240 & 1240.1270 & 1200.1160 & 1220.1260 \\
\hline $\mathrm{H}(\mathrm{CN})$ & 1010 & 990 & 1000 & 1020 \\
\hline $\mathrm{H}(\mathrm{CN})$ & 812 & 840 & 850.700 & 870.750 \\
\hline $\mathrm{H}(\mathrm{CN})$ & 674.513 & 650 & 670 & 680 \\
\hline
\end{tabular}

In the high-frequency region $3380,3320 \mathrm{sm}^{-1}$ There are signs of absorption of stretching vibrations of water molecules around them. It should be emphasized that in the region of 3070-3160 $\mathrm{sm}^{-1}$ and $2350-2815 \mathrm{sm}^{-1}$, many traces of absorption. It is related with the inner molecular interactions and through molecules. Take for instance, oxygen atom of phosphate acid remain and hydrogen atom of methyl group of hexamethylenetetramine remains participate in forming hydrogen bond. This kind of traces of absorption can be seen in lots of compounds like that. The tracks observed at 1025-1040 and $980 \mathrm{sm}^{-1}$ correspond to the stretching vibrations of the $\mathrm{RO}_{4}^{-3}$ group. According to the information on the base of the analysis of IR-specter, the protonation of hexamethylenetetramine base, nitrogen atom on the account of acid protons. New compounds will be generated as an interaction of acid-base [13-17].

Taking everything into account, results, taken on the base of studying melting level in $\left[\begin{array}{lllll}22 \% & \mathrm{H}_{3} \mathrm{PO}_{4}+78 \% & \left.\mathrm{H}_{2} \mathrm{O}\right] & -\end{array}\right.$ $\left(\mathrm{CH}_{2}\right)_{6} \mathrm{~N}_{4}-\mathrm{C}_{5} \mathrm{H}_{6} \mathrm{O}_{2}$ system, lead to the creation of new technology of getting new rust modifiers on the base of extractive phosphate acid, furfural alcohol and hexamethylenetetramine.

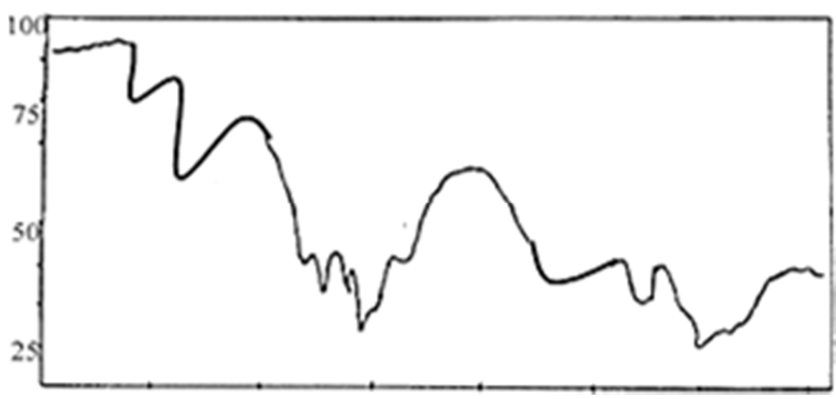

Figure 1. New compounds $\left(\mathrm{CH}_{2}\right)_{6} \mathrm{~N}_{4}$ IR-specters.

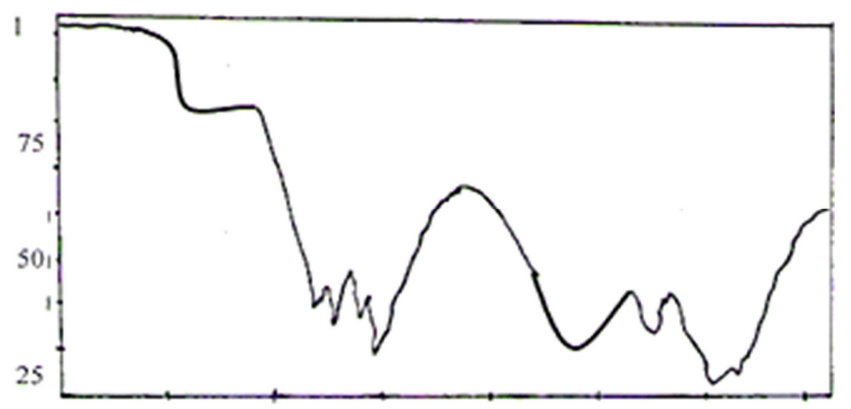

Figure 2. New compounds $\left(\mathrm{CH}_{2}\right)_{6} \mathrm{~N}_{4} \cdot \mathrm{H}_{3} \mathrm{PO}_{4} \cdot \mathrm{H}_{2} \mathrm{O}$ IR-specters. 
100

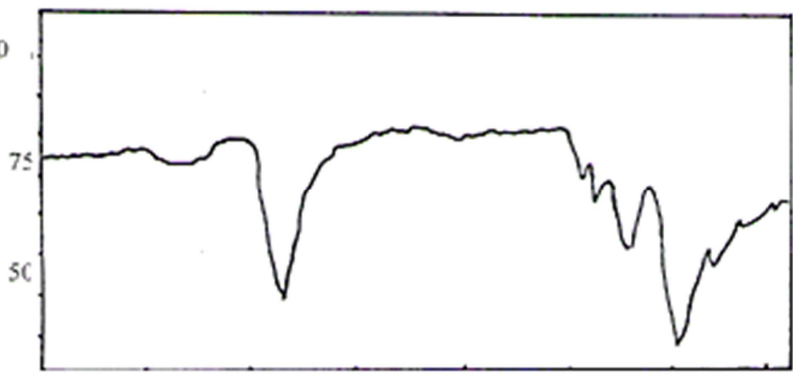

Figure 3. New compounds $\left(\mathrm{CH}_{2}\right)_{6} \mathrm{~N}_{4} \cdot \mathrm{H}_{3} \mathrm{PO}_{4} \cdot 2 \mathrm{H}_{2} \mathrm{O}$ IR-specters.

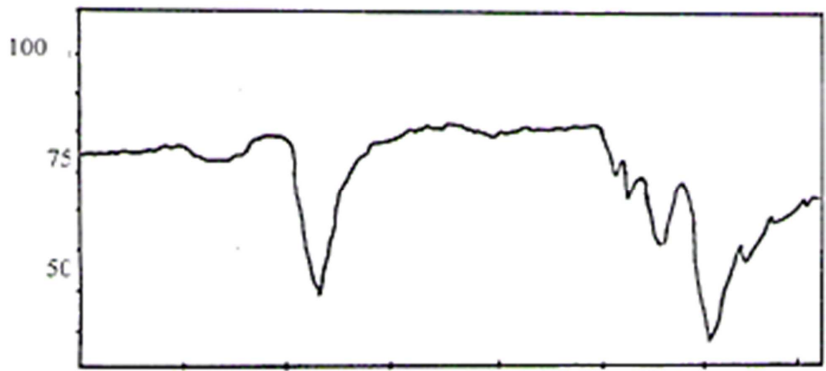

Figure 4. New compounds $\left(\mathrm{CH}_{2}\right)_{6} \mathrm{~N}_{4} \cdot \mathrm{H}_{3} \mathrm{PO}_{4} \cdot 4 \mathrm{H}_{2} \mathrm{O}$ IR-specters.

\section{Conclusion}

All the above-mentioned information serve to the base of creating new technology of getting new rust modifiers on the base of extractive phosphate acid, furfural alcohol and hexamethylenetetramine. These compositions without passivating the metal surfaces, give an opportunity of modifying the rust, phosphatizing, providing with the inhibitors that helps to prevent of being rust. In its turns, this leads to make the process easier, saving the composition and having strong protection layer on the surface.

\section{References}

[1] Jumaniyazov M. J, Kurambayev SH, D. M. Jumaniyazova, A. Rajabov, Ruzmetov S. Searching metal inhibitors againstmetal rusting on the base of hydrolysis lignin. // U. AS «Bulletin of Khorezm Ma'mun Academy». Khiva-2007, №143-46 B.

[2] Jumaniyazov M. J., Kurambaev Sh., D. M. Jumaniyazova. Synthesis of new modified forms of hydrolytic lignin and their application. "High technologies and prospects of integration of education, science and production". Proceedings of the International Scientific and Technical Conference, Tashkent2006, 205-207 S.

[3] Jumaniyazov M. J., A. Rajabov., D. M. Jumaniyazova., Kurambaev Sh. The problem of lignin, the sources of its formation and methods of utilization. / J. Urdu "Ilm sarcashmalari" 2006 №2, - 12-15 B.

[4] Jumaniyazov M. J., Yuldashev N. X., Dyusebekov B. D., Xodjaev O. F. The basics of the technology of obtaining antipyretic against Gossipol smoke. // J. Composite materialy. -2002, -№ 4. S. 55-56

[5] Dyusebekov B. D., Alibekov R. S., Jumaniyazov M. J., Yuldashev N. X. Gossypol resin is the most valuable raw material for obtaining products of national economic importance. Resb. scientific-practical. Conf. "Uzb. kimyo talimi, fani va texnosi "-Tashkent., 2002. P. 198-200

[6] Panova O. A., Ivleva I. A., Besedin P. V. Investigation of the structural-rheological properties of the composition in the presence of an alkali-reagent// Cement and its application. 2012. №5. Pp. 94-98.

[7] P. V., Panova O. A., Ivleva I. A. Techniques, patterns and mechanisms of energy conservation on the base of using of plasticizing agents in the technology of making of the cement clinker// Word Applied Sciences Journal. 25 (1): 83-91. 2013

[8] Babushkin V. I., Matveyev G. M., Mchedlov-Petrosyan O. P. Thermodynamics of silicates 4 th ed., Pererab. and additional. Moscow: Stroiizdat, 1986. 408 p.

[9] Eitel V. Physical chemistry of silicates. Moscow: Publishing House of Foreign Literature, 1962. 1056 p.

[10] Prigogine I., Defay R. Chemical Thermodynamics. Novosibirsk: Science, Siberian Division, 1966. 512 p.

[11] Guzman I. Y. Chemical technology of ceramics. Textbook. manual for universities. M. OOO RIF "Stroimaterialy", 2003. $496 \mathrm{p}$.

[12] Besedin P. V., Ivleva I. A., Mospan V. I. Heat-efficient wall material // Glass and ceramics. 2005. № 6. P. 24-25.

[13] Dulkina, T. I. Gzhel. Ceramics of 18-19 centuries. Ceramics of the 20th century / T. I. Dulkina, N. S. Grigor'eva, TL. Astrakhantsev. - Moscow: Planet; Edition 2-e, corrected. and add., 2016. - $184 \mathrm{c}$.

[14] Sidorova, N. A. Antique painted ceramics / N. A. Sidorova, O. V. Tugusheva, V. S. Zabelina. - Moscow: Art, 2016. - 228 c.

[15] Arzumanova, OI Keramika Abramtseva in the meeting of the Moscow State University of Engineering Ecology / O. I. Arzumanova, V. A. Lyubartovich, M. V. Nashchokina. Moscow: Giraffe, 2015. - 224 c.

[16] Salakhov AM, Morozov VP, Gumarov AI, Ariskina K. A., Valimukhametova AR, Lis ON, Pasynkov M. V. Experience of surface treatment of ceramic materials for construction purposes // Building materials. 2017. № 4. P. 42-46.

[17] Saenko EG, Korepanova VF, Grinfeld GI. Opportunities of clinker clinker brick of LSR brand in import substitution // Building materials. 2016. № 4. P. 60-63. 